Library of Congress budget. The Legislative Branch Appropriation Bil1 (HR 2942) for fiscal year 186 has been passed by both House and Senate. The House acted first, on July 18 , cutting LC's request 8.9 percent, leaving the Library below the ' 85 level. Areas particularly hard hit were preservation, book purchases, automation, and books for the blind.

The Senate on July 31 restored some cuts, including preservation and automation cuts, but the Senate figure of $\$ 220,723,000$, although higher than the House-passed $\$ 216,597,000$, was still below LC's request of $\$ 253,129,000$.

One of the House cuts, of $\$ 103,000$, was designed to prohibit LC from reproducing and distributing playboy in braille. The amendment was offered on the floor by Rep. Chalmers Wylie (R-OH) and passed 216-193. The Senate did not restore the funds, leaving the House cut and the intent behind it intact.

Librarian of Congress Daniel Boorstin in a statement expressed "profound regret" at the House action "censoring material made available to the blind community through our Library of Congress service. The next step might be to deny funds to the Library of Congress for purchase of books which the House deemed inappropriate, subversive, or unacceptable to the majority of the House. Censorship has no place in a free society."

LC's National Library Service for the Blind and Physically Handicapped is authorized by law to provide reading materials to those who cannot read ordinary print. It selects items with the help of its readers and librarians based on the premise that users should have access to the same books and information made available to the non-handicapped through public libraries. However, the cost of reproducing materials in braille and in recorded format means NLS must be selective. Only 36 magazines are available in braille; Playboy is one of the more popular. Playboy in braille includes only selected print material, no pictorial material or captions, and has been produced since 1970.

NEH 20th Anniversary. "In Celebration of the Humanities: The 20th Anniversary Year of the National Endowment for the Humanities"--this motto is the theme for a year-1ong celebration beginning in september of the birth of the NEH. The National Humanities Alliance, of which ALA is a member, is urging libraries to help celebrate the humanities, and the contributions of $\mathrm{NEH}$ in particular.

Libraries are encouraged to sponsor celebratory events such as exhibits, symposia, forums, film festivals, discussion groups, or use the anniversary theme in already scheduled events. For more information or to report planned events, contact Marsha Wice, Ex. Dir., National Humanities Alliance, P.0. Box 2293, Hoya Station, Washington, DC 20057, 202/625-4039. 


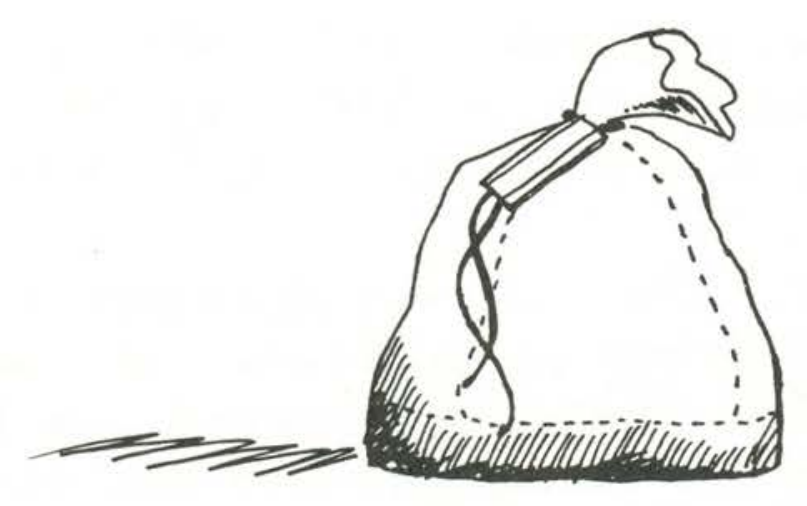

\section{the goods}

Data Courier delivers the goods. And we do it first-class.

We have copyright clearance to deliver photocopies of most full-text articles appearing in more than 650 publications cited in the ABI/INFORM ${ }^{\circledR}$ database.

We deliver quickly. Articles ordered before 2 p.m. (Eastern time) are shipped the next business day. Rush services also are available.
We deliver economically. The cost is $\$ 8.25$ per article or only $\$ 6.75$ if you open a deposit account for $\$ 100$.

Order from Data Courier online, or by telephone, mail, facsimile transmission or telex.

We do the rest. Data Courier Inc, 800/626-2823 in the continental United States, 800/626-0307 in Canada, 502/582-4111. Or telex 20435. 